\title{
PERILAKU KERUNTUHAN BALOK BETON MUTU NORMAL DAERAH TEKAN
}

\author{
YETRO BAYANO \\ Pegawai Negeri Sipil \\ Balai Besar Pelaksanaan Jalan Nasional XI \\ Direktorat Jenderal Bina Marga Kementerian Pekerjaan Umum
}

\begin{abstract}
ABSTRAK
Tulangan sengkang vertikal berfungsi untuk mencegah terjadinya retak pada balok akibat gaya geser, karena berfungsi untuk mengikat antara bagian balok di bawah retak geser dan bagian balok di atas retak geser. Retak geser pada balok tidak akan terjadi jika tulangan sengkang vertikal direncanakan dengan tepat untuk menahan gaya geser tersebut. Pada daerah tekan/ditengah bentang, pengaturan jarak antar sengkang perlu dilakukan untuk menentukan perilaku keruntuhan dari suatu struktur balok.

Untuk menganalisis akibat pengaturan jarak antar sengkang ditengah bentang pada struktur balok, model dengan jarak antar sengkang ditengah bentang masing-masing 40;80;120;150;125; 100; 75 dan 50 $\mathrm{mm}$. Analisis model menggunakan program komputasi ANSYS Ed.9.0. Model material beton menggunakan model SOLID65 dengan parameter nilai tegangan-regangan beton dihitung menggunakan persamaan usulan Kent and Park untuk beton mutu normal dan model material baja tulangan menggunakan model LINK8 dengan parameter nilai tegangan-regangan baja tulangan dihitung menggunakan persamaan usulan Park and Paulay untuk beton mutu normal. Model baja tumpuan perletakan balok dan tumpuan beban menggunakan SOLID45 dan diasumsikan bersifat linier. Analisis model balok untuk menentukan perubahan nilai bebandeformasi, daktilitas struktur balok.

Berdasarkan hasil analisis model balok dengan analisis model elemen hingga menggunakan ANSYS Ed.9.0 Nilai beban ultimit pada model dengan jarak antar sengkang ditengah bentang 40, 80 dan $120 \mathrm{~mm}$, nilainya turun berturut-turut pada rasio $1.0000 ; 0.9621 ; 0.9242$ menjadi sebesar 29.7000; 28.5750; 27.4500 $\mathrm{kN}$. Nilai beban ultimit pada model dengan jarak antar sengkang ditengah bentang 150; 125; 100; 75; dan 50 $\mathrm{mm}$, nilainya naik berturut-turut pada rasio $1.0000 ; 1.0256 ; 1.0351 ; 1.0586 ; 1.0628$ menjadi sebesar 42.2250 ; 43.3350; 43.7400; 44.7300; $44.9100 \mathrm{kN}$. Nilai daktilitas kurvatur pada model dengan jarak antar sengkang ditengah bentang 40, 80 dan $120 \mathrm{~mm}$, nilainya turun berturut-turut pada rasio $1.0000 ; 0.8667 ; 0.6842$ menjadi sebesar 15.3864; 13.3333; 10.5263. Nilai daktilitas kurvatur pada model dengan jarak antar sengkang ditengah bentang $150 ; 125 ; 100 ; 75$; dan $50 \mathrm{~mm}$, nilainya naik berturut-turut pada rasio $1.0000 ; 1.1081 ; 1.1714$; $1.2424 ; 1.3667$ menjadi sebesar $4.8780 ; 5.4054 ; 5.7143 ; 6.0606 ; 6.6667$.

Dari hasil analisis diperoleh beberapa persamaan untuk menentukan perilaku balok akibat variasi jarak antar sengkang didaerah tekan yaitu persamaan daktilitas kurvatur-dan jarak antar sengkang, dimana $\mu_{\varphi}=-2.10^{-}$ ${ }^{5} S^{3}+0.005 . S^{2}-0.688 . S+30.58$; dengan nilai $\mu_{\varphi}$ adalah daktilitas kurvatur, satuan dalam $1 / \mathrm{mm}$ dan $S$ adalah jarak antar sengkang ditengah bentang, satuan dalam mm, serta persamaan beban dan deformasi pada kondisi ultimit akibat variasi jarak antar sengkang didaerah tekan, dimana $=0,002 \Delta^{2}+0,817 \Delta$; dengan nilai $P$ adalah beban yang terjadi pada balok, satuan dalam $\mathrm{kN}$ dan $\Delta$ adalah deformasi yang terjadi pada balok, satuan dalam $\mathrm{mm}$.
\end{abstract}

Kata Kunci : Balok Beton Mutu Normal; Jarak Antar Sengkang; Daerah Kritis; ANSYS Ed.9.0; Beban-Deformasi; Daktilitas Kurvatur. 


\section{PENDAHULUAN}

\section{Latar Belakang}

Beton adalah material konstruksi yang banyak dipakai sampai saat ini dibandingkan dengan material lain seperti kayu dan baja. Hal ini dikarenakan material penyusunnya mudah didapat, mempunyai kekuatan yang baik, keawetan, proses produksinya lebih cepat dan sederhana serta harga yang terjangkau.

Secara umum beton digolongkan menjadi 2 golongan, yaitu beton mutu normal dan beton mutu tinggi. Beton mutu normal adalah beton yang mempunyai mutu berkisar 20 sampai dengan 58 $\mathrm{MPa}$ dan dibuat menggunakan agregat alam yang dipecah atau tanpa dipecah. Sedangkan beton mutu tinggi adalah beton yang mempunyai mutu diatas 58 MPa dan dibuat menggunakan agregat alam yang dipecah atau agregat buatan dengan campuran bahan tambah serta metode pelaksanaan yang disesuaikan dengan kebutuhan kuat tekannya (SNI-03-28472002).

Penggunaan beton mutu normal dalam berbagai bidang konstruksi secara umum sudah banyak digunakan, salah satunya adalah struktur balok beton mutu normal. Aplikasi pembebanan yang besar pada balok beton mutu normal dan melebihi kapasitas penampang berdasarkan kuat tekannya, dapat membuat retak dan keruntuhan dari struktur balok tersebut. Perilaku retak dan keruntuhan yang terjadi pada balok beton mutu normal berupa keruntuhan lentur dan keruntuhan geser. Pada keruntuhan lentur, penggunaan tulangan tarik lentur bertulangan rangkap dengan pengaturan jarak sengkang dapat meminimalkan keruntuhan yang terjadi. Hal ini dikarenakan dengan penambahan tulangan lentur rangkap pada balok beton mutu normal membuat kapasitas rotasi penampang balok menjadi bertambah. Jarak sengkang yang lebih rapat membuat kekuatan beton yang terkekang didalam struktur balok menjadi bertambah karena struktur betonnya lebih termampatkan. Pada keruntuhan geser, penggunaan tulangan lateral dan pengaturan jarak sengkang dapat membuat perilaku keruntuhan berubah dari keruntuhan geser ke arah keruntuhan lentur dengan kapasitas penampang yang bertambah naik. Hal ini dikarenakan kekuatan beton yang terkekang tulangan tarik dan tekan serta tulangan lateral dan sengkang didalam struktur balok menjadi bertambah karena struktur betonnya lebih termampatkan kearah lentur (Dipohusodo, I. 1994).
Dari uraian diatas, bagian tulangan sengkang pada arah vertikal adalah tulangan yang berhubungan langsung dengan keretakan geser tersebut. Tulangan ini mencegah terbelahnya balok akibat adanya keretakan geser, karena berfungsi untuk mengikat antara bagian balok di bawah retak geser dan bagian balok di atas retak geser. Retak geser pada balok tidak akan terjadi jika direncanakan dengan tepat untuk menahan gaya geser tersebut (Kennet, M.L. 1997).

\section{Perumusan Masalah}

Dalam penelitian ini, dirumuskan permasalahan sebagai berikut:

1. Analisis dilakukan dengan memodelkan balok beton mutu normal dari hasil uji eksperimental terdahulu oleh Basuki (Basuki. Hidayati, N. 2006) dan divariasikan dengan jarak antar sengkang ditengah bentang, mutu dan diameter baja tulangan lentur dan tarik, mutu beton dan panjang bentang model balok.

2. Analisis model menggunakan ANSYS Ed.9.0 untuk menentukan nilai beban-deformasi, daktilitas kurvatur dan perilaku keruntuhan yang terjadi akibat varasi jarak antar sengkang ditengah bentang.

\section{Tujuan Penelitian}

Tujuan dalam penelitian adalah untuk menentukan perubahan nilai beban-deformasi, daktilitas kurvatur dan perilaku keruntuhan yang terjadi akibat variasi jarak antar sengkang di tengah bentang pada model balok beton mutu normal.

\section{Manfaat Penelitian}

Manfaat dari penelitian ini adalah dengan variasi model, maka dapat ditentukan pengaruh pengaturan jarak antar sengkang ditengah bentang pada model balok beton mutu normal terhadap peningkatkan nilai kapasitas beban-deformasi, daktilitas kurvatur dan perilaku keruntuhan yang terjadi pada model balok.

\section{Asumsi yang dipergunakan}

Model beton dimodelkan menggunakan material SOLID65. Nilai tegangan dan regangan model balok beton mutu normal diperoleh berdasarkan hasil perhitungan tegangan-regangan beton mutu normal menggunakan usulan Kent and Park (Park, R. Paulay, T. 1975) untuk kondisi beton terkekang. Sedangkan model baja tulangan lentur dan tulangan sengkang dimodelkan menggunakan material LINK8. Nilai tegangan dan regangan baja 
tulangan hasil analisis tegangan-regangan untuk baja tulangan untuk beton mutu normal menggunakan usulan dari Park and Paulay (Park, $R$. Paulay, T. 1975). Model tumpuan perletakan pada model balok persegi dan tumpuan beban menggunakan SOLID45 dan model ini diasumsikan bersifat linier.

Analisis elemen hingga dengan bantuan program komputasi ANSYS Ed.9.0 pada model balok untuk menentukan perubahan nilai bebandeformasi, daktilitas kurvatur dan perilaku keruntuhan yang terjadi akibat variasi jarak antar sengkang ditengah bentang pada model balok beton mutu normal.

\section{Batasan Masalah}

Batasan yang digunakan dalam penelitian ini adalah sebagai berikut:

1. Model balok analisis menggunakan model balok berdasarkan hasil uji eksperimental oleh Basuki (Basuki. Hidayati, N. 2006).

2. Mutu beton mutu normal yang digunakan $\left(f^{\prime}{ }^{\prime}\right)$ 20,38 dan 25,00 MPa.

3. Mutu baja tulangan lentur $\left(f_{y}\right)$ yang digunakan adalah 252,01 dan 400,00 MPa.

4. Diameter baja tulangan lentur yang digunakan adalah 7,44 dan $16,00 \mathrm{~mm}$.

5. Mutu baja tulangan sengkang $\left(f_{y s}\right)$ yang digunakan adalah $240 \mathrm{MPa}$.

6. Diameter baja tulangan sengkang yang digunakan adalah 4,00 dan 8,00 mm.

7. Analisis tegangan-regangan untuk beton mutu normal menggunakan Persamaan usulan Kent and Park (Park, R. Paulay, T. 1975) untuk kondisi beton terkekang.

8. Analisis tegangan-regangan untuk baja tulangan untuk beton mutu normal menggunakan Persamaan usulan Park and Paulay (Park, R. Paulay, T. 1975).

\section{KAJIAN PUSTAKA}

\section{Landasan Teori}

\section{Balok Beton Mutu Normal}

Secara umum beton digolongkan menjadi 2 golongan, yaitu beton mutu normal dan beton mutu tinggi. Beton mutu normal adalah beton yang mempunyai mutu beton berkisar 20 sampai dengan $58 \mathrm{MPa}$ dan dibuat menggunakan agregat alam yang dipecah atau tanpa dipecah. Dalam campuran beton, agregat kasar, agregat halus, dan semen yang bereaksi dengan air sebagai bahan perekat, yang harus dicampur dan diaduk dengan benar dan merata agar dapat diperoleh mutu beton yang baik.

Umumnya pengadukan bahan beton dilakukan dengan menggunakan mesin, kecuali jika hanya untuk mendapatkan beton mutu rendah, maka pengadukan dapat dilakukan tanpa menggunakan mesin pengaduk (SNI 03-2847-2002).

Balok beton bertulang adalah beton yang ditulangi dengan luas dan jumlah tulangan yang tidak kurang dari nilai minimum, yang disyaratkan dengan atau tanpa prategang, dan direncanakan berdasarkan asumsi bahwa kedua material bekerja bersama-sama dalam menahan gaya yang berkerja (SNI 03-2847-2002).

\section{Kuat Tekan dan Kuat Tarik Beton Mutu Normal}

Kuat tekan beton diwakili oleh tegangan tekan karakterisitik, $\mathrm{f}_{\mathrm{c}}$ dengan satuan $\mathrm{N} / \mathrm{mm}^{2}$ atau $\mathrm{MPa}$. Struktur beton mutu normal umumnya menggunakan beton dengan kuat tekan 20 sampai dengan $58 \mathrm{MPa}$ (Kusuma, G. 1997).

Nilai regangan kerja maksimum yang diperhitungkan di serat tepi beton tekan terluar adalah 0,003 sebagai batas hancur. Regangan kerja maksimum 0,003 tersebut boleh jadi tidak konservatif untuk beton kuat tinggi dengan nilai kuat tekan beton antara 55 sampai dengan $80 \mathrm{MPa}$. Nilai kuat tekan dan tarik beton tidak berbanding lurus. Setiap usaha perbaikan mutu kekuatan tekan hanya disertai peningkatan kecil nilai kuat tariknya. Suatu perkiraan kasar yang dapat dipakai, bahwa nilai kuat tarik beton normal antara 9 sampai dengan $15 \%$ (prosen) dari nilai kuat tekannya. Kuat tarik beton yang tepat sulit untuk diukur. Nilai pendekatan yang diperoleh dari hasil pengujian terdahulu mencapai kekuatan 0,50 sampai dengan 0,60 kali dari akar kuadrat nilai kuat tekannya. Sehingga untuk beton mutu normal, nilai kuat tarik beton digunakan $0,60 \cdot \sqrt{\tilde{\digamma}_{\mathrm{c}}}($ SNI 03-2847-2002).

\section{Kuat Geser pada Balok Beton Mutu Normal}

Lingkaran Mohr digunakan untuk menunjukkan bahwa tegangan normal maksimum dan minimum akan bekerja pada dua bidang yang saling tegak lurus satu sama lainnya. Bidang tersebut dinamakan bidang utama dan tegangan yang bekerja disebut tegangan utama seperti tercantum dalam gambar dibawah ini: 


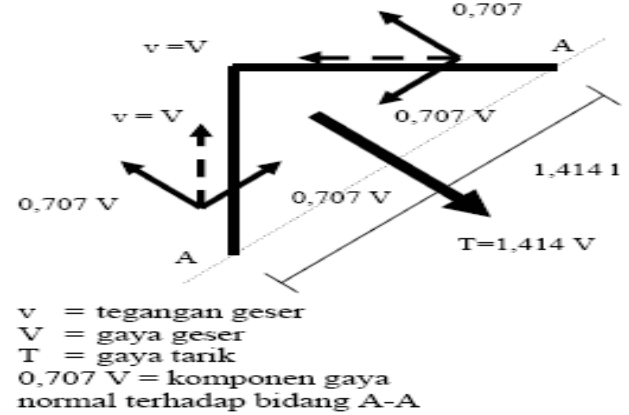

\section{Perencanaan Penulangan Geser}

Perencanaan geser untuk komponen struktur terlentur didasarkan pada anggapan bahwa beton menahan sebagian dari gaya geser, sedangkan kelebihannya/kekuatan geser di atas kemampuan beton untuk menahannya dilimpahkan kepada tulangan baja geser. Cara yang umum dilaksanakan dan lebih sering dipakai untuk penulangan geser adalah menggunakan sengkang, selain pelaksanaannya lebih mudah juga menjamin ketepatan pemasangannya. Penulangan dengan sengkang hanya memberikan andil terhadap sebagian pertahanan geser karena formasi/arah retak yang miring. Cara penulangan demikian terbukti mampu memberikan sumbangan untuk peningkatan kuat geser ultimit komponen struktur yang mengalami lenturan.

Untuk komponen struktur yang menahan geser dan lentur saja, memberikan kapasitas kemampuan beton (tanpa penulangan geser) untuk menahan gaya geser adalah $V_{c}$, dimana $V_{c}$ dihitung menggunakan persamaan 2.1 (SNI 03-2847-2002):

$V_{c}={ }_{6}^{1} \sqrt{f^{i}} b_{w}, d$

Atau menggunakan persamaan 2.1b (SNI 03-28472002):

$V_{v}=\frac{1}{7}\left(\sqrt{f^{\prime}}+120 \cdot \rho_{w} \cdot\left(\frac{u_{u} \cdot d}{M_{u}}\right) \cdot b_{w} \cdot d\right.$

dengan $M_{u}$ adalah momen terfaktor yang terjadi bersamaan dengan gaya geser terfaktor maksimum $V_{u}$ pada penampang kritis, sedangkan batas atas faktor pengali dan $V_{u}$ dihitung menggunakan persamaan 2.1c dan 2.1d (SNI 03-2847-2002):

$\frac{V_{w d} d}{N_{u L}} \leq 1,0$

$v_{c} \leq\left(0,3 . f^{\prime}{ }_{e}\right) \cdot b_{w} d$

Pada persamaan 2.1, $V_{c}$ adalah kuat geser beton; $f_{c}{ }_{c}$ adalah kuat tekan beton; $b_{w}$ adalah lebar efektif penampang balok; $\rho_{w}$ adalah ratio luas tulangan lentur dengan luas penampang balok; $M_{u}$ adalah momen akibat beban luar yang bekerja. Kuat geser ideal beton dikenakan faktor reduksi kekuatan dimana nilai $\varphi$ adalah 0,60 , sedangkan kuat geser rencana $V_{u}$ didapatkan dari hasil penerapan faktor beban, nilai $V_{u}$ lebih mudah ditentukan dengan menggunakan diagram gaya geser (SNI 03-28472002).

Meskipun secara teoritis tidak perlu penulangan geser apabila $V_{u} \leq \varphi V_{c}$, peraturan mengharuskan untuk selalu menyediakan penulangan geser minimum pada semua bagian struktur beton yang mengalami lenturan meskipun hasil perhitungan tidak memerlukannya, kecuali untuk plat dan fondasi plat, struktur balok beton rusuk, balok yang tinggi totalnya tidak lebih dari 250 $\mathrm{mm}$, atau 2,5 kali tebal flens, atau 1,5 kali lebar badan balok, diambil yang lebih besar dihitung dengan persamaan 2.1e. Ketentuan tulangan geser minimum tersebut untuk menjaga apabila timbul beban yang tak terduga pada komponen.

Dimana, $A_{v}$ adalah luas penampang tulangan geser total dengan jarak spasi antar tulangan $S$, untuk sengkang keliling tunggal $A_{v}=2 . A_{s}$, dengan $A_{s}$ luas penampang batang tulangan sengkang; $b_{w}$ adalah lebar balok, untuk balok persegi $b_{w}=b ; S$ adalah jarak pusat ke pusat batang tulangan geser ke arah sejajar tulangan pokok memanjang; $f_{y s}$ adalah kuat leleh tulangan geser (SNI 03-2847-2002).

Apabila gaya geser yang bekerja $V_{u}$ lebih besar dari kapasitas geser beton $\varphi V_{c}$, maka diperlukan penulangan geser untuk memperkuatnya. Apabila gaya geser yang bekerja di sembarang tempat sepanjang bentang lebih besar dari $1 / 2 . \varphi . V_{c}$, peraturan mengharuskan memasang paling tidak tulangan geser mini(auha) yang disyaratkan. Persamaan dasar untuk perencanaan tulangan geser adalah:

$\mathrm{V}_{\mathrm{u}} \leq \varphi \cdot \mathrm{V}_{\mathrm{n}}$

$\mathrm{V}_{\mathrm{n}}=\mathrm{V}_{\mathrm{c}}+\mathrm{V}_{\mathrm{s}}$

Dimana, $V_{u}$ adalah beban geser terfaktor; $\varphi$ adalah faktor reduksi kuat geser; $V_{c}$ adalah kuat geser beton; $V_{n}$ adalah kuat geser ideal atau nominal; $V_{s}$ adalah kuat geser nominal yang dapat disediakan oleh tulangan geser (SNI 03-2847-2002).

Nilai $V_{s}$ untuk(2.q1 kang vertikal, dapat dihitung dengan menggunakan persamaan:

$V_{w}=\frac{A_{v} f_{g} d}{s}$

\section{Kurva Tegangan-Regangan Tekan Beton Mutu Normal}


Nilai tegangan-regangan beton untuk beton mutu normal menggunakan usulan Kent and Park (Park, R. Paulay, T. 1975) dengan parameter perhitungan tercantum dalam

Pada kurva tegangan-regangan usulan Kent and Park dalam Gambar 2.4, kurva dimulai dari tegangan awal dititik A yang nilainya terus naik sampai mencapai puncak tegangan di B dengan nilai tegangan sama dengan $f_{c}^{\prime}$ dan regangan puncak beton pada nilai 0,002 . Setelah mencapai puncak tegangan di titik $\mathrm{B}$, tegangan yang terjadi turun namun nilai regangannya terus bertambah sampai mencapai keruntuhan dititik $\mathrm{C}$ dengan nilai tegangan sebesar $0,2 f^{\prime}{ }_{c}$ dan nilai regangan sebesar $\varepsilon_{20 c}$. Setelah mencapai nilai regangan $\varepsilon_{20 c}$ nilai tegangan yang terjadi adalah konstan.

$$
Z-\frac{0,5}{\varepsilon_{\text {soul }}+\varepsilon_{\text {soh }}-0,002}
$$

Berdasarkan kurva dalam Gambar 2.4, diperoleh persamaan dengan membagi kurva menjadi 3 daerah, yaitu:

Daerah $\mathrm{AB}: \varepsilon_{c} \leq 0,002$

$f_{t}=f_{c}^{\prime}\left[\frac{2 x_{\varepsilon}}{0,002}-\left(\frac{x_{v}}{0,002}\right)^{2}\right]$

Daerah BC : $0,002<\varepsilon_{\mathrm{c}}<\varepsilon_{20 \mathrm{c}}$

$f_{e}=f_{e}^{\prime}\left[1-Z\left(\varepsilon_{e}-0,002\right)\right]$

Daerah CD : $\varepsilon_{c} \geq \varepsilon_{20 c}$

$f_{t}=0,2 f^{\prime}$

dimana :

$\varepsilon_{50 u}=\frac{3+2,002 f_{c}^{\prime}}{f_{e}^{\prime}-1000}$

$\varepsilon_{50 h}=\frac{3}{4} \rho_{s} \sqrt{\frac{b^{h}}{s_{h}}}$

Pada Persamaan 2.5, $f_{c}^{\prime}$ adalah kuat tekan beton, satuan dalam $p s i ; \rho_{s}$ adalah perbandingan volume tulangan melintang terhadap inti beton yang diukur terhadap bagian luar sengkang; $b$ " adalah lebar inti kekekangan diukur terhadap bagian luar sengkang, satuan dalam $\mathrm{mm} ; s_{h}$ adalah jarak antar sengkang, satuan dalam $\mathrm{mm} ; \varepsilon_{c}$ adalah regangan tekan beton; $\varepsilon_{20 c}$ adalah regangan tekan beton pada saat nilai tegangan tekan beton mencapai $0,20 f^{\prime}$.

\section{Kurva Tegangan-Regangan Baja Tulangan}

Perhitungan untuk menentukan nilai tegangan dan regangan baja tulangan menggunakan usulan Park and Paulay (Park, R. Paulay, T. 1975) dengan parameter perhitungan tercantum dalam Gambar 2.5.

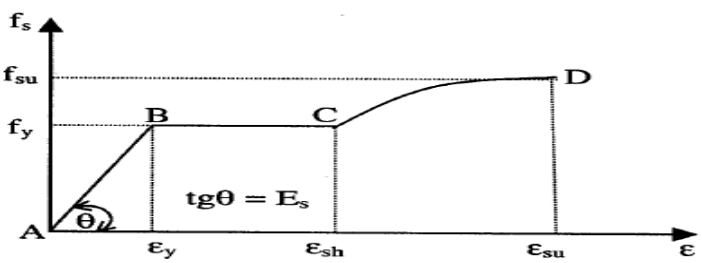

Gambar 2.5 Kurva hubungan tegangan-regangan baja tulangan usulan Park and Paulay (Park, R. Paulay, T. 1975).

Pada kurva tegangan-regangan usulan Park and Paulay dalam Gambar 2.5, kurva dimulai dari tegangan awal dititik A yang nilainya terus naik sampai mencapai puncak tegangan di B dengan nilai tegangan sama dengan $f_{y}$ dan regangan leleh pada nilai $\varepsilon_{y}$. Setelah mencapai puncak tegangan di titik $\mathrm{B}$, tegangan yang terjadi adalah tetap namun nilai regangannya terus bertambah sampai regangan plastis $\varepsilon_{s h}$ dititik C. Pada saat mencapai batas regangan plastis dititik $\mathrm{C}$, nilia tegangan yang terjadi akan naik kembali sampai mencapai kondisi keruntuhan dititik D dengan nilai tegangan sebesar $f_{s u}$ dan nilai regangan sebesar $\varepsilon_{s u}$. Berdasarkan kurva dalam Gambar 2.5, dipesal)eh persamaan dengan membagi kurva menjadi 3 daerah, yaitu:

Daerah $\mathrm{AB}: \varepsilon_{s} \leq \varepsilon_{y} \quad(2.5 \mathrm{~b})$

$f_{s}=\varepsilon_{s} \cdot E_{s}$

Daerah BC : $\varepsilon_{y} \leq \varepsilon_{s}<\varepsilon_{s h}$

$f_{s}=f_{y}$

Daerah CD : $\varepsilon_{s h} \leq \varepsilon_{s}<\varepsilon_{s u}$

$f_{s}=f_{y}\left[\frac{m\left(\varepsilon_{g}-\varepsilon_{s h}\right)+2}{6 J\left(x_{g}-s_{s h}\right)+2}+\frac{(6-2-5 g))(60-m)}{1(30 v+1)^{2}}\right]$

dimana :

$m=\frac{\left(f_{\text {Sur }} / \delta_{y}\right)(30 r+1)^{2}-60 r-1}{15 m^{2}}$

$\mathrm{r}=\varepsilon_{s u}-\varepsilon_{s h}$

Pada Persamaan 2.6, $f_{s}$ adalah kuat tarik baja tulangan, satuan dalam $\mathrm{MPa} ; \varepsilon_{s}$ adalah regangan tarik baja tulangan; $\varepsilon_{s h}$ adalah regangan tarik baja tulangan pada saat mencapai batas plastis; $\varepsilon_{s u}$ adalah regangan tarik baja tulangan pada saat mencapai kondisi ultimit. $E_{s}$ adalah modulus elastisitas baja tulangan, satuan dalam MPa.

Analisis Daktilitas Kurvatur Beton Mutu Normal Kondisi Terkekang

Nilai daktilitas kurvatur adalah membandingkan antara sudut kelengkungan saat 
ultimit dan sudut kelengkungan pada saat terjadi leleh pertama pada tulangan tarik dari model balok akibat beban lentur, sehingga diperoleh suatu hubungan nilai momen-kurvatur. Dalam penelitian ini, analisis untuk menentukan nilai momen dan kurvatur menggunakan modifikasi blok teganganregangan usulan Kent and Park untuk beton mutu normal kondisi terkekang (Park, R. Paulay, T. 1975). Dari analisis modifikasi blok teganganregangan pada kondisi awal retak, leleh dan ultimit, maka dapat ditentukan nilai daktilitas kurvatur dari balok beton mutu normal dengan pengaturan jarak antar sengkang ditengah bentang balok.

Berdasarkan persamaan usulan Kent and Park pada Persamaan 2.5 dan Gambar 2.4, diperoleh 3 daerah kurva, yaitu kurva naik $\mathrm{AB}$, kurva turun BC dan kurva datar CD. Dengan modifikasi blok tegangan-regangan pada Gambar 2.4, dapat ditentukan nilai parameter perhitungan menggunakan blok tegangan-regangan balok beton mutu normal yaitu nilai $\alpha$ dan $\gamma$ untuk setiap daerah. Untuk memperoleh nilai $\alpha_{i}$ dan $\gamma_{i}$ dari setiap daerah kurva secara langsung, maka perhitungannya harus memenuhi syarat-syarat sebagai berikut (Park, R . Paulay, T. 1975):

1) Luas daerah diagram tegangan beton sebenarnya harus sama dengan luas blok tegangan ekivalen. Luas daerah dibagi dalam 3 (tiga) zona seperti tercantum dalam Gambar 2.6.

2) Sentroid diagram tegangan beton sebenarnya berlokasi sama dengan sentroid blok tegangan ekivalen.

Dengan penurunan rumus dari Persamaan 5 pada kurva tegangan-regangan beton mutu normal kondisi beton terkekang usulan Kent and Park seperti yang tercantum dalam Gambar 2.4, maka diperoleh nilai $\alpha_{i}$ dan $\gamma_{i}$ dari setiap daerah kurva, yaitu (Park, R. Paulay, T. 1975):

Zona 1, Kurva naik, A-B $\left(\varepsilon_{c l} \leq 0,002\right)$ :

$$
\begin{aligned}
& \alpha_{1}=\frac{\varepsilon_{c 1}}{0,002} \cdot\left(1-\frac{\varepsilon_{c 1}}{0,006}\right) \\
& \gamma_{1}=\frac{0,008-\varepsilon_{c 1}}{0,024-4 \cdot \varepsilon_{c 1}}
\end{aligned}
$$

Zona 2, Kurva turun, B-C $\left(0,002 \leq \varepsilon_{c 2} \leq \varepsilon_{c 20}\right)$ :

$$
\begin{aligned}
& \alpha_{2}=\frac{0,004}{3 \cdot \varepsilon_{c 2}}+\left(1-\frac{0,002}{\varepsilon_{c 2}}\right) \cdot\left(1-\frac{Z}{2} \cdot\left(\varepsilon_{c 2}-0,002\right)\right) \cdot \\
& \gamma_{2}=1-\frac{-\frac{3,334 \cdot 10^{-7}}{\varepsilon_{c 2}}+0,5 \cdot \varepsilon_{c 2}-0,333 \cdot Z \cdot \varepsilon_{c 2}{ }^{2}+0,001 \cdot Z \cdot \varepsilon_{c 2}-\frac{1,33410^{-9}}{\varepsilon_{c 2}} \cdot Z}{-\left(6,667 \cdot 10^{-4}\right)+\varepsilon_{c 2}-0,5 \cdot Z \cdot \varepsilon_{c 2}{ }^{2}+0,002 \cdot Z \cdot \varepsilon_{c 2}-2 \cdot 10^{-6} \cdot Z}
\end{aligned}
$$

Zona 2, Kurva datar, C-D $\left(\varepsilon_{c 3} \geq \varepsilon_{c 20}\right)$ :

$$
\begin{aligned}
& \alpha_{3}=\frac{-6,667 \cdot 10^{-4}}{\varepsilon_{c 3}}+0,8 \cdot \frac{\varepsilon_{20 x}}{\varepsilon_{c 3}}-0,5 \cdot Z \cdot \frac{\varepsilon_{20}{ }^{2}}{\varepsilon_{c 3}}+0,002 \cdot Z \cdot \frac{\varepsilon_{20 x}}{\varepsilon_{c 3}}-\frac{2 \cdot 10^{-6}}{\varepsilon_{c 3}} \cdot Z+0,2 \cdot
\end{aligned}
$$

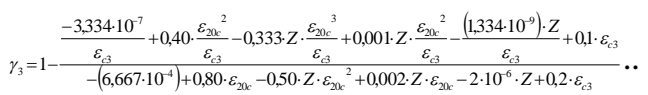

Dari persamaan 2.7, $\alpha_{1}$ adalah koefisien pengali lebar blok tegangan ekivalen beton mutu normal pada zona $1 ; \gamma_{1}$ adalah koefisien pengali tinggi blok tegangan ekivalen beton mutu tinggi pada zona $1 ; \alpha_{2}$ adalah koefisien pengali lebar blok tegangan ekivalen beton mutu normal pada zona 2; $\gamma_{2}$ adalah koefisien pengali tinggi blok tegangan ekivalen beton mutu normal pada zona $2 ; \alpha_{3}$ adalah koefisien pengali lebar blok tegangan ekivalen beton mutu normal pada zona $3 ; \gamma_{3}$ adalah koefisien pengali tinggi blok tegangan ekivalen beton mutu normal pada zona 3 .

Koefisien tinggi dan lebar blok tegangan ekivalen pada model balok seperti yang tercantum dalam Gambar 2.6, nilai parameter tegangan regangan disubstitusikan menggunakan nilai $\alpha_{i}$ dan $\gamma_{i}$ pada setiap zone luasan. Modifikasi blok tegangan-regangan dilakukan untuk memperhitungkan pengaruh mutu beton pada nilai $\alpha_{i}$ dan $\gamma_{i}$ dari model balok.

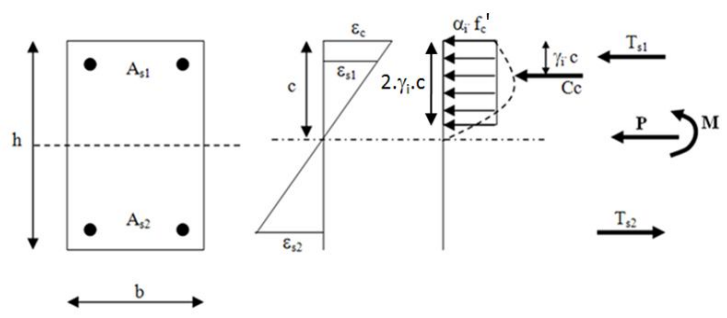

Gambar 2.7 Analisis Penampang Balok Beton Mutu Normal Menggunakan Parameter Blok TeganganRegangan Usulan Kent and Park untuk Menghitung MomenKurvatur (Park, R. Paulay, T. 1975).

\section{Analisa Elemen Hingga Model Menggunakan ANSYS Ed.9.0}

\section{Model Beton}

Model balok dalam ANSYS Ed.9.0 menggunakan model material concrete SOLID65 yang mampu menggambarkan perilaku retak dan pecah dari beton, seperti tercantum dalam Gambar 2.8 . 


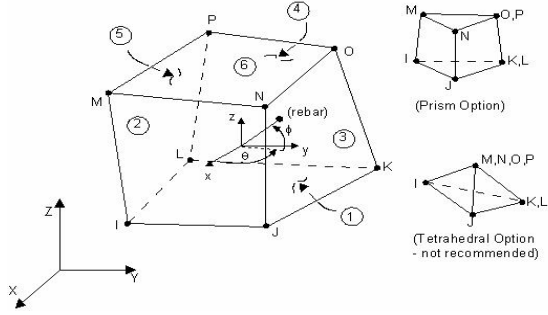

Gambar 2.8 Geometri elemen concrete SOLID65 (ANSYS Ed.9.0, 2007)

1) Input data material model concrete SOLID65 sebagai berikut :

a. Kuat tekan beton diperoleh dari hasil pengujian terdahulu.

b. Modulus elastisitas beton $\left(E_{c}\right)$

c. Poisson rasio untuk beton digunakan 0,20.

d. Kuat tarik beton

e. Nilai tegangan-regangan hasil pengujian dimasukan kedalam multilinier kinematic hardening plasticity.

2) Retak dan kehancuran beton

Perilaku elastic isotropic pada beton terjadi pada saat sebelum beton mengalami retak awal atau posisi akan mengalami kehancuran awal, seperti yang tercantum dalam Gambar 2.9 dan 2.10. Kehancuran (crushing) beton didefinisikan sebagai pelepasan suatu unsur dari satu kesatuan material (ANSYS Manual, 2007).

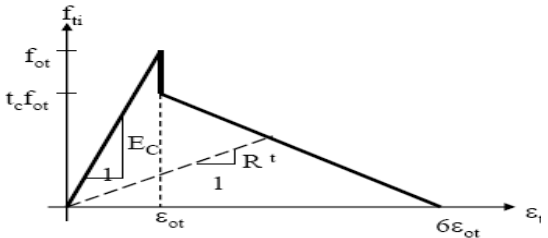

Gambar 2.9 Kurva tegangan-regangan beton dalam ANSYS Ed.9.0 (ANSYS. 2007).

3) Parameter kegagalan pada permukaan beton dalam ANSYS dimodelkan dalam 5 (lima) pada nonlinier nonmetal plasticity concrete, seperti yang tercantum dalam Gambar 2.10, yaitu :

a. Koefisien transfer geser awal untuk retak pada beton, dengan nilai antara 0.00 sampai dengan 1.00, dimana nilai 0.00 menggambarkan retak halus dan nilai 1.00 menggambarkan retak yang kasar. Untuk beton mutu normal digunakan nilai 0.10 sebagai nilai referensi, sedangkan untuk beton mutu tinggi, tidak ada literatur maupun referensi mengenai nilai yang pasti. Untuk itu digunakan nilai pendekatan dalam penelitian ini, yaitu sebesar 0.90 . b. Koefisien transfer geser akhir untuk retak pada beton, pada penelitian ini digunakan nilai sebesar 1.00 .

c. Kuat tarik uniaksial $\left(f_{r}\right)$, yaitu tegangan tarik retak beton dimana nilainya mendekati atau sama dengan nilai modulus pecah beton.

d. Tegangan tekan hancur beton uniaksial $\left(f^{\prime}{ }_{c u}\right)$, yaitu tegangan tekan beton dengan nilai antara sama dengan nilai tegangan ultimitnya. Nilai $-1,00$ menggambarkan model balok tidak akan mengalami keruntuhan pada kondisi nilai pembebanan yang tak terbatas sedangkan nilai ultimitnya

\section{Model baja tulangan}

1) Model baja tulangan pada model balok menggunakan material model elemen spar LINK8. Digunakannya material model elemen spar LINK8 karena material ini mampu menggambarkan tegangan dan regangan plastis, rayapan, pengembangan, kekakuan tegangan dan deformasi yang besar seperti perilaku baja tulangan. Model spar LINK8 merupakan elemen tiga dimensi yang didefiniskan dengan 2 nodes dan merupakan sebuah material yang isotropic. Geometri struktur elemen spar LINK8 tercantum dalam Gambar 2.11.

2) Data masukan untuk material model baja tulangan menggunakan elemen non linier rate independent multilinier isotropic hardening dan von-mises yield criterian dengan nilai modulus young, poisson ratio dan kurva teganganregangan baja tulangan.

\section{Model tumpuan balok}

1) Model tumpuan perletakan dan tumpuan beban pada model balok menggunakan pelat baja solid. Dalam ANSYS Ed.9.0 digunakan model material elemen bricknode8 SOLID45. Model bricknode8 SOLID45 mempunyai 8 (delapan) nodes

2) Digunakannya material model elemen bricknode8 SOLID45 karena material ini mampu menggambarkan tegangan dan regangan elastis, kekakuan tegangan dan deformasi yang besar seperti perilaku pelat baja tumpuan. Model elemen bricknode8 SOLID45 merupakan material yang isotropic dan dapat bekerja dengan material lain seperti model beton concrete SOLID65. Geometri dan letak nodes dari elemen bricknode8 SOLID45 dalam Gambar 2.29. 


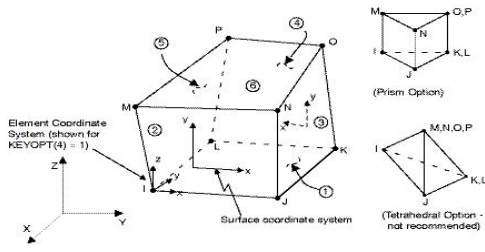

\section{METODE PENELITIAN}

\section{Pendekatan Sistem}

Model balok beton mutu normal dengan pengaruh pengekangan didaerah tekan akan dimodelkan berdasarkan variabel dalam batasan penelitian pada bab sebelumnya. Analisa model balok persegi menggunakan analisa elemen hingga dengan bantuan program komputasi ANSYS Ed.9.0. Model beton mutu normal pada balok dimodelkan menggunakan material SOLID65. Nilai tegangan dan regangan beton mutu normal diperoleh berdasarkan dari perhitungan matematik menggunakan usulan Kent and Park. Sedangkan model baja tulangan pada Model balok persegi dimodelkan menggunakan material LINK8. Nilai tegangan dan regangan baja tulangan diperoleh berdasarkan dari perhitungan matematik menggunakan usulan Park and Paulay (Park, R. Paulay, T. 1975). Model tumpuan perletakan pada model balok dan tumpuan menggunakan model material SOLID45 dan model ini diasumsikan bersifat linier.

Analisa elemen hingga dengan bantuan program komputasi ANSYS Ed.9.0 pada model balok untuk menentukan perubahan nilai bebandeformasi; beban-retak; dan perilaku retak akibat pengaturan jarak sengkang pada daerah tekan. Sehingga dapat dihitung nilai daktilitas kurvatur dan perilaku keruntuhan dari model balok tersebut. Kurang atau sama dengan $20 \%$, maka data telah tervalidasi dan dapat digunakan untuk mengambil kesimpulan dari hasil analisis model yang dimaksud.

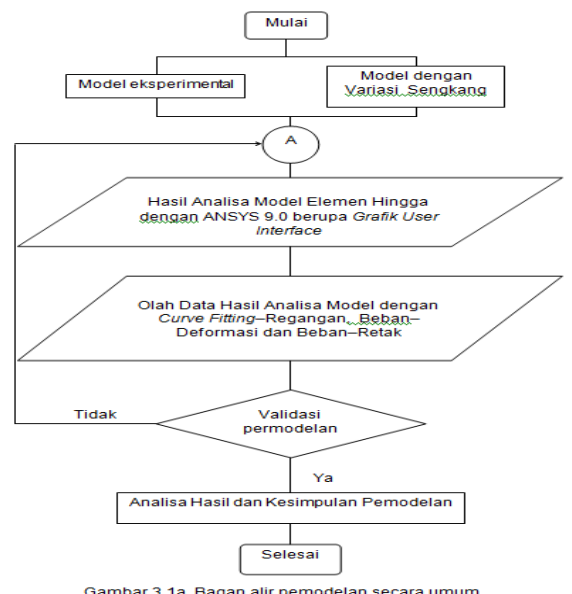

\section{Model Beton}

1) Model beton pada model balok dalam program ANSYS Ed.9.0 menggunakan elemen model concrete SOLID65. Digunakannya material model concrete SOLID65 karena mampu menggambarkan perilaku retak dalam tiga sumbu koordinat, kehancuran, deformasi plastis dan rayapan seperti

2) Model beton. Material model concrete SOLID65 dapat bekerja bersama dengan material lain, misalnya baja tulangan. Model ini didefinisikan dalam delapan nodes dan merupakan material yang isotropic.

3) Perilaku elastic isotropic pada model beton terjadi pada saat sebelum beton mengalami retak awal atau posisi akan mengalami kehancuran awal pada kurva teganganregangan beton dalam ANSYS Ed.9.0. Kehancuran (crushing) beton didefinisikan sebagai pelepasan suatu unsur dari satu kesatuan material. Parameter retak dan kehancuran pada permukaan beton dalam ANSYS Ed.9.0 dimodelkan pada data masukan material model nonlinier nonmetal plasticity concrete:

e. Koefisien transfer geser awal untuk retak pada beton, dengan nilai antara 0,00 sampai dengan 1,00 , dimana nilai 0,00 menggambarkan retak halus dan nilai 1,00 menggambarkan retak yang kasar. Untuk beton mutu normal digunakan nilai 0.30 sebagai nilai referensi, sedangkan untuk beton mutu tinggi,

f. Penelitian ini digunakan nilai pendekatan yaitu sebesar 0,50. Hal ini dimungkinkan dapat mendekati gambaran retak yang terjadi pada beton mutu tinggi.

g. Koefisien transfer geser akhir untuk retak pada beton, pada penelitian ini digunakan nilai sebesar 1,00.

h. Kuat tarik uniaksial $\left(f_{r}\right)$, yaitu tegangan tarik retak beton dimana nilainya mendekati atau sama dengan nilai modulus pecah beton.

i. Tegangan tekan hancur beton uniaksial $\left(f_{c u}^{\prime}\right)$, yaitu tegangan tekan beton dengan nilai sama dengan tegangan ultimit beton yang menggambarkan model dapat mengalami keruntuhan pada saat beban ultimit diberikan.

Kuat tekan ultimit untuk tekanan hidrostatis uniaksial $\left(f_{2}\right)$, yaitu tegangan tekan hidrostatis beton arah uniaksial dengan nilainya sebesar $1,725 . f^{\prime}$. 


\section{Model Baja Tulangan}

1) Model baja tulangan pada model balok dalam program ANSYS Ed.9.0 menggunakan material model elemen spar LINK8. Digunakannya material model elemen spar LINK8 karena material ini mampu menggambarkan tegangan dan regangan plastis, rayapan, pengembangan, kekakuan tegangan dan deformasi yang besar seperti perilaku baja tulangan. Model ini merupakan elemen tiga dimensi yang didefiniskan dengan 2 nodes dan merupakan sebuah material yang isotropic.

2) Data untuk material model baja tulangan menggunakan elemen non linier rate independent multilinier isotropic hardening dan von-Mises yield criterian dengan nilai Young modulus, poisson ratio dan nilai kurva tegangan-regangan baja berdasarkan persamaan usulan Park and Paulay.

\section{Model Baja Tumpuan}

1) Model tumpuan perletakan dan tumpuan beban pada model balok menggunakan pelat baja solid. Dalam ANSYS Ed.9.0 digunakan model material elemen bricknode8 SOLID45. Model bricknode8 SOLID45 mempunyai 8 (delapan) nodes dengan 3 (tiga) derajat kebebasan translasi pada arah sumbu koordinat $\mathrm{x}, \mathrm{y}$ dan $\mathrm{z}$.

2) Digunakannya material model elemen bricknode8 SOLID45 karena material ini mampu menggambarkan tegangan dan regangan elastis, kekakuan tegangan dan deformasi yang besar seperti perilaku pelat baja tumpuan. Model elemen bricknode8 SOLID45 merupakan material yang isotropic dan dapat bekerja dengan material lain seperti model beton concrete SOLID65. Geometri dan letak nodes dari elemen bricknode8 SOLID45 dalam Gambar 2.29.

3) Dalam penelitian ini sifat tegangan dan regangan model elemen bricknode8 SOLID45 adalah elastis linier dan diasumsikan tidak terpengaruh akibat pembebanan. Hal ini karena sifat dari model pelat baja tumpuan harus mempunyai kekuatan yang cukup dan tidak hancur meskipun model balok sudah mengalami keruntuhan.

\section{Prosedur Pelaksanaan}

Pembuatan model balok dalam ANSYS Ed.9.0 dijelaskan dibawah ini:

1) Jenis referensi model yang akan dibuat. Ansys main menu, preferences pilih structural.

2) Model beton dan baja tulangan dibuat tipe materialnya.
Ansys main menu, preprocessor, element type pilih add

Tipe 1, model beton, pilih solid concrete65.

Tipe 2, model baja tulangan utama, pilih link spar 8.

Tipe 3, model baja tulangan geser, pilih link spar 8.

3) Setting untuk definisi tipe elemen.

Ansys main menu, preprocessor, real constant pilih add

Set 1 untuk model definisi tipe material 1 dengan elemen tipe 1

Set 2 untuk model definisi tipe material 2 dengan elemen tipe 2, dan seterusnya sampai semua tipe model material terdefinisi (beton, baja tulangan utama, baja tulangan sayap, baja tulangan sengkang)

Data masukan parameter real constant untuk model validasi eksperimental dan model eksperimental dengan variasi jarak sengkang tercantum dalam Tabel 3.1.

1) Model dibentuk dan dimensinya disesuaikan dengan batasan parameternya

2) Model disusun dari beberapa bagian meshing nodes yang disusun menjadi blok nodes. Pembuatan bagian meshing nodes disesuaikan dengan jarak antar as tulangan utama, tulangan sayap, tulangan sengkang serta baja tumpuan beban dan tumpuan perletakan balok. Blok nodes yang telah disusun menjadi beberapa blok nodes kemudian dibentuk menjadi sebuah balok yang tipikal dengan dimensi yang telah disesuaikan.

Ansys main menu, preprocessor, modeling, create, volume, block, by dimensions.

\section{Implementasi Model}

Balok persegi yang digunakan dalam analisis elemen hingga dengan ANSYS Ed.9.0 ada 2 (dua) jenis model, yaitu balok persegi sesuai hasil eksperimental oleh Basuki (Basuki. Hidayati, $N$. 2006) dan balok persegi sesuai uji eksperimental terdahulu

\section{Jumlah model}

Jumlah model ditentukan berdasarkan variasi parameter yang tertera dalam batasan penelitian. Adapun jumlah model analisa elemen hingga menggunakan ANSYS Ed.9.0 dengan variasi material properties model tercantum dalam Tabel 3.2 . 
Gambar 3.2a. Model Balok YT40.40.01 untuk validasi eksperimental terdahulu. (aa) penampang melintang. (ab) penampang memanjang (satuan dalam $\mathrm{mm})$

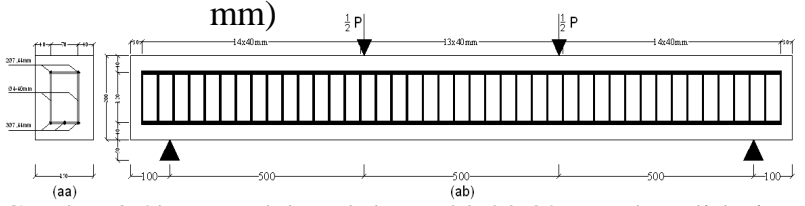

Gambar 3.2b. Model Balok YT80.80.02 untuk validasi eksperimental terdahulu. (ba) penampang melintang. (bb) penampang memanjang (satuan dalam mm)

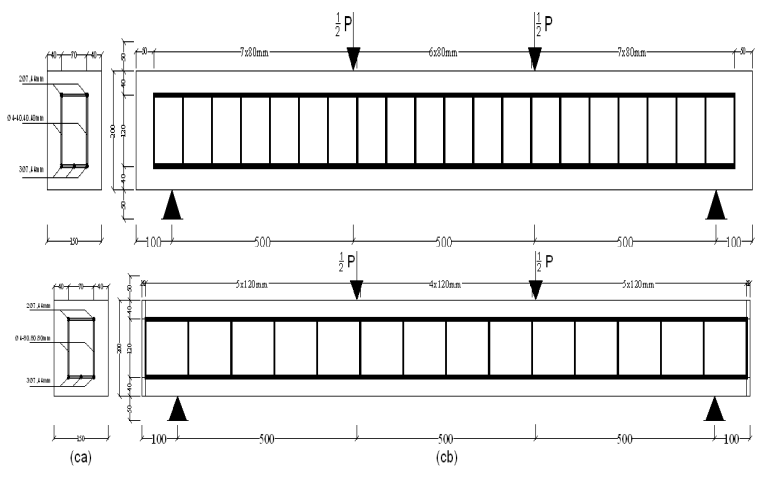

T120.120.03 untuk validasi eksperimental terdahulu. (ca) penampang melintang. (cb) penampang memanjang (satuan dalam $\mathrm{mm}$ )

Dalam ANSYS Ed.9.0, sebelum dilakukan analisis adalah mengkondisikan batas perletakan yang digunakan, yaitu pada ujung balok bentang parsial (pada bentang penuh berada ditengah bentang) dan ujung penampang melintang (pada penampang penuh berada ditengah penampang), dibuat perletakan rol-rol agar model balok dapat bertranslasi-rotasi arah Y dan Z seperti pada kondisi balok ditengah bentang pada model balok bentang dan penampang penuh. Hal ini dilakukan agar tercapai kondisi model balok simetris dan sama dengan model balok bentang dan penampang penuh. Analogi model balok parsial simetris dengan analisis model elemen hingga menggunakan ANSYS Ed.9.0 tercantum dalam Gambar

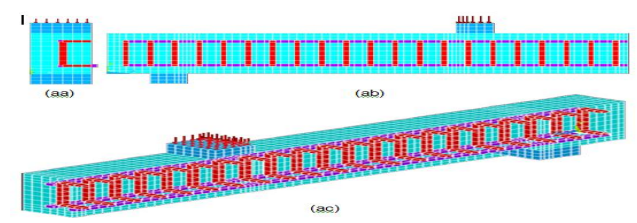

Gambar 3.4a. Implementasi model balok kondisi simetrisntuk YT40.40.01 dalam ANSYS Ed.9.0. (aa) penampang melintang balok. (ab) penampang memanjang balok. (ac) penampang tiga dimensi balok.

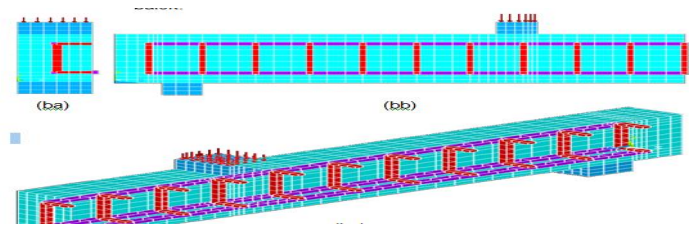

Gambar 3.4b. Implementasi model balok kondisi simetris untuk YT80.80.02 dalam ANSYS Ed.9.0. (ba) penampang melintang balok. (bb) penampang memanjang balok. (bc) penampang tiga dimensi balok

Gambar 3.4c. Implement Model balok kondisi simetris untuk YT120.120.03 dalam ANSYS Ed.9.0. (ca) penampang melintang balok. (cb) penampang memanjang balok. (cc) penampang tiga dimensi balok.

\subsection{Validasi dan Verifikasi Model}

Analisis awal yang dilakukan adalah memodelkan balok persegi dengan data masukan yang sesuai dengan hasil uji eksperimental oleh Basuki (Basuki. Hidayati, N. 2006). Model kemudian dianalisis dan kemudian hasilnya dibandingkan dengan hasil uji eksperimental. Apabila hasil sudah tervalidasi maka akan dilanjutkan dengan pembuatan model dengan variasi yang telah ditetapkan dalam batasan penelitian. Hasil analisis model ini akan dibandingkan dengan hasil model awal.

Dari hasil analisa model elemen hingga dengan bantuan program ANSYS Ed.9.0 tersebut diperoleh data berupa nilai tegangan-regangan, beban-deformasi, dan beban-retak. Nilai tersebut diolah menjadi sebuah data yang menyerupai data koordinat. Data berupa koordinat yang ada merupakan data koordinat yang acak. Dari data koordinat tersebut, maka dapat ditentukan persamaan kurvanya menggunakan regresi polynomial metode curve fitting power model fungsi parabolik dalam suatu persamaan polynomial yang baru yang dapat dijadikan usulan untuk hasil penelitian ini.

\section{IMPLEMENTASI MODEL DAN VALIDASI}

\section{Analisis Model Menggunakan Pendekatan Matematik}

Model balok yang akan dianalisis manual menggunakan model pendekatan dengan perhitungan matematik. Langkah ini dilakukan agar diperoleh nilai validasi yang mendekati hasil eksperimental terdahulu. Dari hasil analisis model 
menggunakan model pendekatan dengan perhitungan matematik tersebut diperoleh data berupa nilai momen-kurvatur-daktilitas, bebandeformasi dari model balok yang dianalisis.

\section{Momen-Kurvatur-Daktilitas Model Balok}

Perhitungan momen dan kurvatur yang terjadi pada model balok menggunakan modifikasi blok tegangan-regangan untuk beton mutu normal kondisi terkekang berbagai kondisi pembebanan, yaitu kondisi awal retak, kondisi leleh pertama dan kondisi ultimit. Rincian perhitungan untuk memperoleh nilai momen-kurvaturnya tercantum dalam lampiran perhitungan analisis daktilitas kurvatur menggunakan metode Kent and Park.

Tabel 4.1a. Nilai Momen dan Kurvatur Model Balok YT40.40.01; YT80.80.02; YT120.120.03 pada Kondisi Awal Retak, Leleh dan Ultimit Hasil

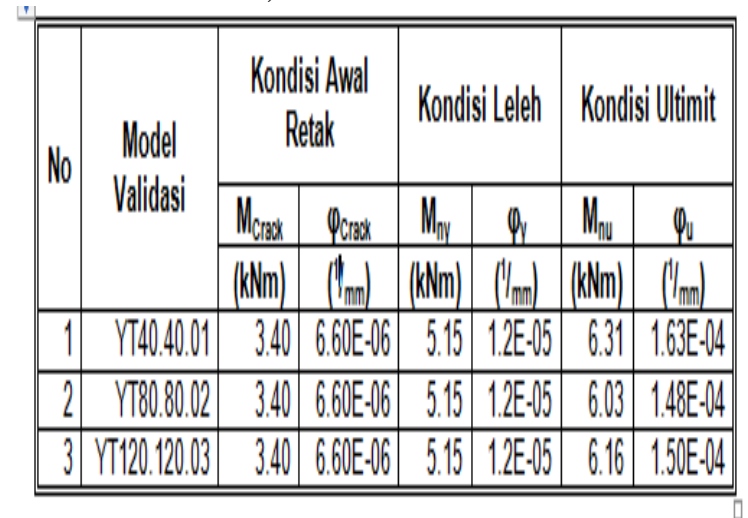

Perhitungan Menggunakan Kurva Tegangan-Regangan Kent and Park

Berdasarkan perhitungan yang tercantum dalam Lampiran perhitungan analisis daktilitas kurvatur menggunakan metode Kent and Park, maka dapat dibuat kedalam suatu kurva hubungan nilai momen dan kurvatur yang terjadi dari model balok seperti tercantum dalam Tabel 4.1a; 4.1b; 4.1c; 4.1d dan Gambar 4.1a; 4.1b; 4.1c.

Tabel 4.1a; 4.1b; 4.1c; 4.1d dan Gambar 4.1a; 4.1b; 4.1c, untuk model YT40.40.01; YT80.80.02; YT120.120.03, nilai momen ultimit terhadap jarak antar sengkang 40, 80 dan $120 \mathrm{~mm}$, nilainya turun berturut-turut pada rasio $1.00 ; 0.96 ; 0.82$ sebesar $6.31 ; 6.03 ; 5.16$ kNm. Untuk model YT150.150.04; YT150.125.05; $\quad$ YT150.100.06; YT150.75.07; YT150.50.08, nilai momen ultimit terhadap jarak antar sengkang $150 ; 125 ; 100 ; 75$; dan $50 \mathrm{~mm}$, nilainya naik berturut-turut pada rasio $1.00 ; 1.0001$; $1.0002 ; 1.0017 ; 1.0022$ menjadi sebesar 33.20; $33.20 ; 33.22 ; 33.25 ; 33.27 \mathrm{kNm}$.
Tabel 4.1b. Nilai Mom dan Kurvatur Model Balok YT150.150.04; $\quad$ YT150.125.05; YT150.100.06; $\quad$ YT150.75.07; YT150.50.08 pada Kondisi Awal Retak, Leleh dan Ultimit Hasil

\begin{tabular}{|c|c|c|c|c|c|}
\hline \multirow{3}{*}{ No } & \multirow{3}{*}{$\begin{array}{l}\text { Model } \\
\text { Validasi }\end{array}$} & \multicolumn{2}{|c|}{ Kondisi Ultimit } & \multirow{3}{*}{$\begin{array}{l}\text { Rasio } \\
\mathrm{M}_{\mathcal{U}} / \mathrm{M}_{\mathrm{U} 40}\end{array}$} & \multirow{3}{*}{$\begin{array}{l}\text { Rasio } \\
\varphi_{u} / \varphi_{u 40}\end{array}$} \\
\hline & & $\mathrm{M}_{u}$ & $\varphi_{u}$ & & \\
\hline & & $(\mathrm{kN})$ & $(\mathrm{mm})$ & & \\
\hline (1) & (2) & (3) & (4) & (5) & (6) \\
\hline 1 & YT40.40.01 & 6.31 & $1.63 \mathrm{E}-04$ & 1.0 & 1.00 \\
\hline 2 & YT80.80.02 & 6.03 & $1.48 \mathrm{E}-04$ & 0.98 & 0.92 \\
\hline 3 & YT120.120.03 & 6.16 & $1.50 \mathrm{E}-04$ & 0.96 & 0.91 \\
\hline
\end{tabular}

Terjadi kenaikan momen ultimit untuk model balok YT150.150.04; $\quad$ YT150.125.05; $\quad$ YT150.100.06; YT150.75.07; YT150.50.08 yang lebih tinggi dibanding model balok YT40.40.01; YT80.80.02; YT120.120.03.

Tabel 4.1c. Nilai Momen dan Kurvatur Model Balok YT40.40.01; YT80.80.02; YT120.120.03; pada Kondisi Ultimit Hasil Perhitungan Menggunakan Kurva Tegangan-Regangan Kent and Park

\begin{tabular}{|c|c|c|c|c|c|}
\hline \multirow{3}{*}{ No } & \multirow{3}{*}{$\begin{array}{l}\text { Model } \\
\text { Variasi }\end{array}$} & \multicolumn{2}{|c|}{ Kondisi Ultimit } & \multirow{3}{*}{$\begin{array}{c}\text { Rasio } \\
\mathrm{M}_{\mathrm{u}} / \mathrm{M}_{\mathrm{u} 150}\end{array}$} & \multirow{3}{*}{$\begin{array}{l}\text { Rasio } \\
\varphi_{\mathrm{u}} / \varphi_{\mathrm{u} 15}\end{array}$} \\
\hline & & $M_{u}$ & $\varphi_{u}$ & & \\
\hline & & $(\mathrm{kN})$ & $(\mathrm{mm})$ & & \\
\hline (1) & (2) & (3) & (4) & (5) & (6) \\
\hline 1 & YYT150.150.04 & 33.20 & $6.89 \mathrm{E}-05$ & 1.0000 & 1.00 \\
\hline 2 & YT150.125.05 & 33.20 & $7.62 \mathrm{E}-05$ & 1.0001 & 1.11 \\
\hline 3 & YT150.100.06 & 33.22 & $8.71 \mathrm{E}-05$ & 1.0008 & 1.26 \\
\hline 4 & YT150.75.07 & 33.25 & 9.87E-05 & 1.0017 & 1.43 \\
\hline 5 & YT150.50.08 & 33.27 & $1.84 \mathrm{E}-04$ & 1.0022 & 2.67 \\
\hline
\end{tabular}

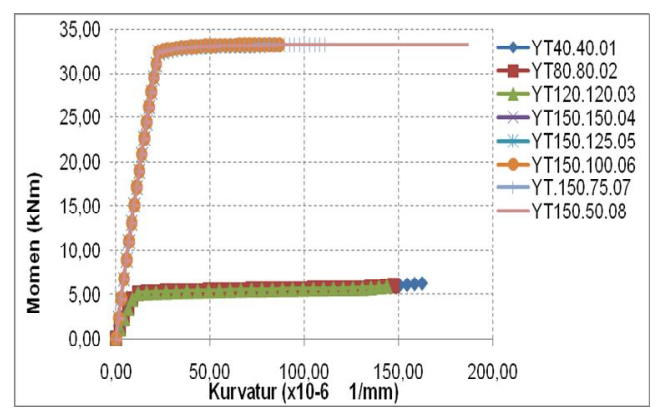

Gambar 4.1a. Kurva Momen dan Kurvatur Model Balok Hasil Perhitungan Menggunakan Kurva TeganganRegangan Kent and Park Untuk Model YT40.40.01; YT80.80.02; YT120.120.03; $\quad$ YT150.150.04; YT150.125.05; $\quad$ YT150.100.06; YT150.75.07 dan YT150.50.08 


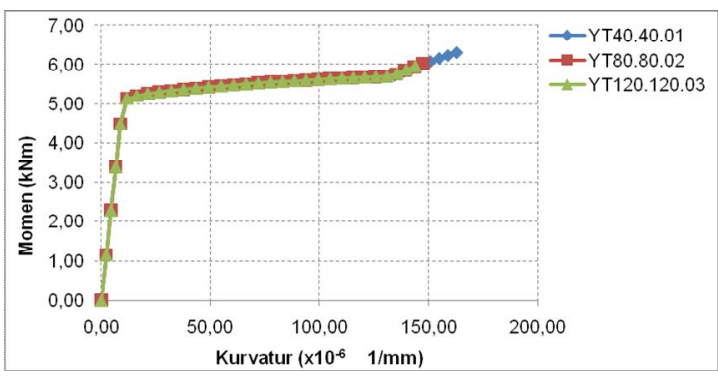

Gambar 4.1b. Kurva Momen dan Kurvatur Model Balok Hasil Perhitungan Menggunakan Kurva TeganganRegangan Kent and Park Untuk Model Validasi Hasil Eksperimental Terdahulu YT40.40.01; YT80.80.02; YT120.120.03

Gambar $4.1 \mathrm{~b}$ adalah kurva hubungan nilai momen dan kurvatur pada model balok hasil eksperimental terdahulu YT40.40.01; YT80.80.02; YT120.120.03; sebagai model validasi. Gambar 4.1c, adalah kurva hubungan nilai momen dan kurvatur pada model balok dengan variasi dari hasil eksperimental terdahulu $\quad$ YT150.150.04; $\quad$ YT150.125.05; YT150.100.06; YT150.75.07 dan YT150.50.08 sebagai model variasi.

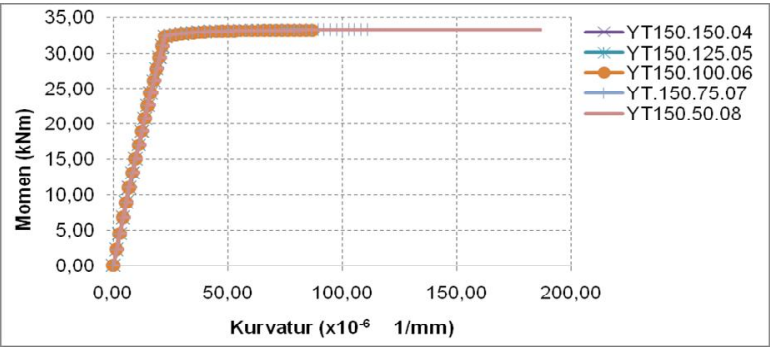

Berdasarkan penjelasan diatas dapat diperoleh suatu persamaan usulan untuk menentukan besarnya daktilitas kurvatur terhadap jarak antar sengkang berdasarkan Gambar 4.3a; 4.3b; 4.3c; 4.3d dan $4.3 \mathrm{e}$ seperti tercantum dalam Gambar 4.3f. Gambar $4.3 \mathrm{~g}$ adalah kurva persamaan daktilitas kurvatur terhadap jarak antar sengkang dari hasil analisis menggunakan ANSYS Ed.9.0. Persamaan kurva regresi polynomial curve fitting berderajat 2 untuk nilai daktilitas kurvatur terhadap jarak antar sengkang adalah:

$\mu_{\varphi}=-2.10^{-5} S^{3}+0.005 . S^{2}-0.688 . S+30.58$, dengan nilai $\mu_{\varphi}$ dan $\mathrm{S}$ masing-masing:

$\mu_{\varphi}=$ Daktilitas kurvatur, satuan dalam $1 / \mathrm{mm}$; bentang, satuan dalam mm.

\section{Beban-Deformasi Model Balok.}

Besarnya nilai beban dan deformasi yang terjadi pada model balok, diperoleh dari hasil konversi nilai tegangan-regangan beton pada model balok hasil analisis menggunakan ANSYS Ed.9.0 seperti tercantum dalam Gambar 4.4. Pada Gambar 4.4, adalah kontur tegangan (von misses stress) pada model balok YT40.40.01; YT80.80.02; YT120.120.03; $\quad$ YT150.150.04; $\quad$ YT150.125.05; YT150.100.06; YT150.75.07 dan YT150.50.08.

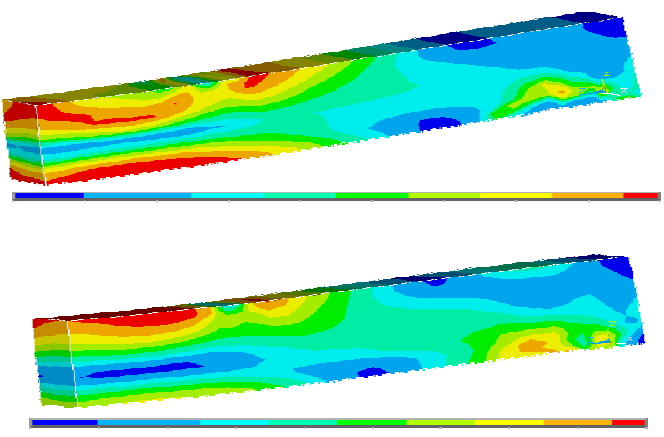

YT150.50.08 tercantum dalam gambar 4.5. Dari Gambar 4.4 untuk model validasi YT40.40.01; YT80.80.02; YT120.120.03; dengan rapatnya jarak sengkang pada daerah tengah bentang, kontur tegangan yang terjadi pada model balok cenderung turun dan perilaku model balok menjadi lebih kuat. Untuk model variasi YT150.150.04; YT150.125.05; YT150.100.06; YT150.75.07 dan YT150.50.08; dengan penambahan mutu beton menjadi $25 \mathrm{MPa}$, naiknya diameter dan mutu baja tulangan menjadi $400 \mathrm{MPa}$, rapatnya jarak sengkang pada daerah tengah bentang, tegangan yang terjadi cenderung turun. Perilaku model balok variasi menjadi lebih kuat dan momen yang mampu ditahan lebih tinggi dibanding model validasi.

Sedangkan kontur deformasi arah Y pada model balok YT40.40.01; YT80.80.02; YT120.120.03; $\quad$ YT150.150.04; $\quad$ YT150.125.05; YT150.100.06; YT150.75.07 dan

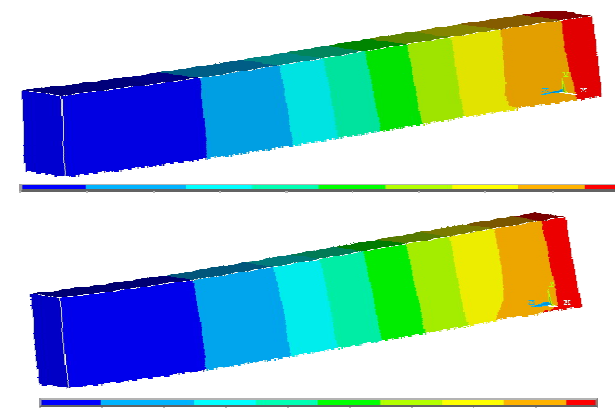

Gambar 4.5. Kontur Deformasi Arah Y (Vertikal) Hasil ANSYS Ed.9.0 untuk Model Balok (a). YT40.40.01;(b). YT80.80.02; (c). YT120.120.03; (d). YT150.150.04;(e).YT150.125.05;(f) YT150.100.06;(g).YT150.75.07;(h). YT150.50.08. 
Berdasarkan hasil analisis menggunakan ANSYS Ed.9.0 diperoleh suatu data hubungan beban dan deformasi seperti yang tercantum dalam Tabel 4.4 dan Gambar 4.5.

Gambar 4.5c. Kurva Beban dan Deformasi Model Balok Variasi dari Hasil Eksperimental Terdahulu YT150.150.04; $\quad$ YT150.125.05; YT150.100.06;

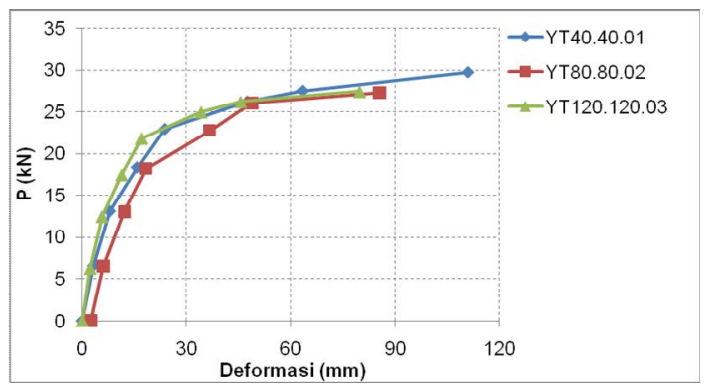

Gambar 4.5c. Kurva Beban dan Deformasi Model Balok Variasi dari Hasil Eksperimental Terdahulu YT150.150.04; $\quad$ YT150.125.05; YT150.100.06; YT150.75.07 YT150.50.08 Hasil ANSYS Ed.9.0

Gambar 4.5d, adalah kurva hubungan nilai beban ultimit dan jarak antar sengkang model balok hasil analisis menggunakan ANSYS Ed.9.0. Untuk model balok validasi hasil eksperimental terdahulu YT40.40.01; YT80.80.02; YT120.120.03; garis kurvanya adalah berupa garis lurus. Untuk model balok variasi dari hasil eksperimental terdahulu YT150.150.04; $\quad$ YT150.125.05; $\quad$ YT150.100.06; YT150.75.07; YT150.50.08 garis kurvanya adalah berupa garis titik garis.

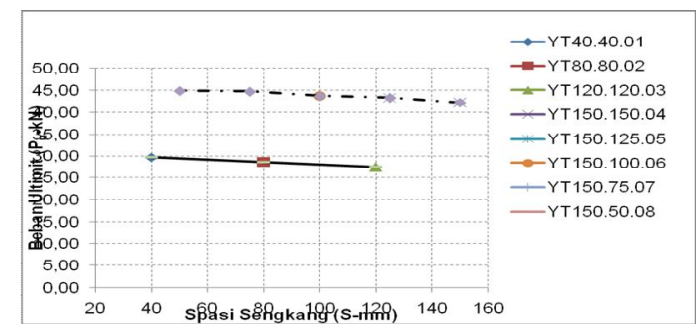

Gambar 4.5d. Trend Kurva Beban Ultimit dan Jarak Antar Sengkang Model Balok YT40.40.01; $\quad$ YT80.80.02; YT120.120.03; $\quad$ YT150.150.04; YT150.125.05; $\quad$ YT150.100.06; YT150.75.07 dan YT150.50.08 Hasil ANSYS Ed.9.0

Pada Gambar 4.5e, adalah kurva hubungan nilai deformasi ultimit dan jarak antar sengkang model balok hasil analisis menggunakan ANSYS Ed.9.0 YT40.40.01; YT80.80.02; YT120.120.03; garis kurvanya adalah berupa garis lurus. Untuk model balok variasi dari hasil eksperimental terdahulu $\quad$ YT150.150.04; $\quad$ YT150.125.05; YT150.100.06; YT150.75.07; YT150.50.08 garis kurvanya adalah berupa garis titik garis.

Dari Tabel 4.4a; 4.4b dan Gambar 4.5a; 4.5b dan 4.5c, untuk model YT40.40.01; YT80.80.02; YT120.120.03, nilai beban ultimit terhadap jarak antar sengkang 40, 80 dan $120 \mathrm{~mm}$ berdasarkan hasil analisis menggunakan ANSYS Ed.9.0, nilainya turun berturut-turut pada rasio 1.0000; 0.9621; 0.9242 menjadi sebesar $29.7000 ; 28.5750 ; 27.4500$ kN. Untuk model YT150.150.04; YT150.125.05; YT150.100.06; YT150.75.07; YT150.50.08, nilai beban ultimit terhadap jarak antar sengkang 150; 125; 100; 75; dan $50 \mathrm{~mm}$ berdasarkan hasil analisis menggunakan ANSYS Ed.9.0, nilainya naik berturut-turut pada rasio $1.0000 ; 1.0256 ; 1.0351$; $1.0586 ; 1.0628$ menjadi sebesar $42.2250 ; 43.3350$; 43.7400; 44.7300; $44.9100 \mathrm{kN}$. Terjadi kenaikan momen ultimit untuk model balok YT150.150.04; YT150.125.05; $\quad$ YT150.100.06; $\quad$ YT150.75.07; YT150.50.08 dibanding model balok

YT40.40.01; YT80.80.02; YT120.120.03. Kenaikan nilai beban ultimit pada model balok YT150.150.04; $\quad$ YT150.125.05; $\quad$ YT150.100.06; YT150.75.07; YT150.50.08 karena nilai mutu beton bertambah menjadi $25 \mathrm{MPa}$ dan diameter serta mutu baja tulangan tarik dan tekan bertambah menjadi 16 $\mathrm{mm}$ dan $400 \mathrm{MPa}$ sehingga kapasitas beban yang mampu ditahan balok juga bertambah.

Nilai deformasi ultimit untuk model YT40.40.01; YT80.80.02; YT120.120.03, terhadap jarak antar sengkang 40, 80 dan 120 mm berdasarkan hasil analisis menggunakan ANSYS Ed.9.0, nilainya turun berturut-turut pada rasio $1.0000 ; 0.7715 ; 0.7196$ menjadi sebesar 110.8897 ; 85.5533; $79.7952 \mathrm{~mm}$. Untuk model YT150.150.04; YT150.125.05; $\quad$ YT150.100.06; $\quad$ YT150.75.07; YT150.50.08, nilai deformasi ultimit terhadap jarak antar sengkang $150 ; 125 ; 100 ; 75$; dan $50 \mathrm{~mm}$ berdasarkan hasil analisis menggunakan ANSYS Ed.9.0, nilainya naik berturut-turut pada rasio $1.0000 ; 1.1199 ; 1.1475 ; 1.1426 ; 1.0958$ menjadi sebesar $152.51 ; 170.37 ; 193.37 ; 222.95 ; 220.37 \mathrm{~mm}$. Terjadi kenaikan kurvatur ultimit untuk model balok YT150.150.04; $\quad$ YT150.125.05; $\quad$ YT150.100.06; YT150.75.07; YT150.50.08 dibanding model balok YT40.40.01; YT80.80.02; YT120.120.03

Berdasarkan penjelasan diatas dapat diperoleh suatu persamaan usulan untuk menentukan 
besarnya beban dan deformasi terhadap jarak antar sengkang berdasarkan Gambar 4.5a; 4.5b; 4.5c; $4.5 \mathrm{~d}$; $4.5 \mathrm{e}$ seperti tercantum dalam Gambar 4.3f. Gambar 4.3f adalah kurva persamaan daktilitas kurvatur terhadap jarak antar sengkang dari hasil analisis menggunakan ANSYS Ed.9.0. Persamaan kurva regresi polynomial curve fitting berderajat 2 untuk nilai beban - deformasi terhadap kenaikan jarak antar sengkang adalah:

$P=0,002 \Delta^{2}+0,817 \Delta$; dengan nilai $\mathrm{P}$ dan $\Delta$ masingmasing:

$\mathrm{P}=$ Beban yang terjadi pada balok, satuan dalam $\mathrm{kN}$; $\Delta=$ Deformasi yang terjadi pada balok, satuan dalam $\mathrm{mm}$.

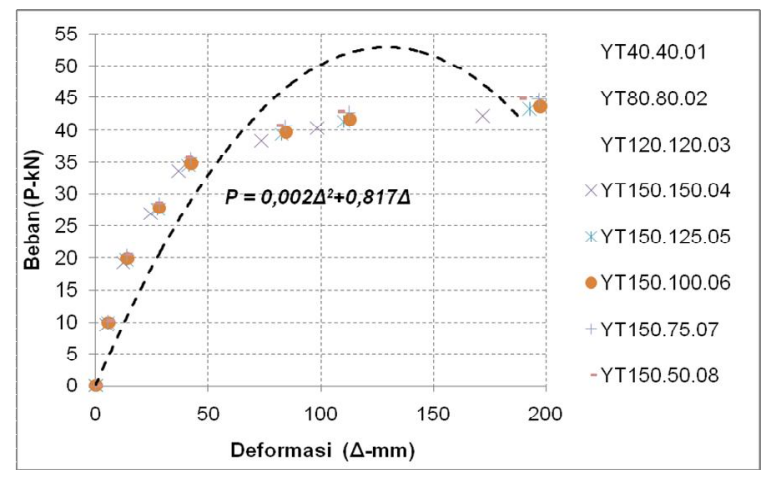

Gambar 4.5f. Persamaan Usulan Kurva Beban dan Deformasi Model Balok Hasil Regresi Polynomial Curve Fitting Berderajat 2.

\section{KESIMPULAN DAN SARAN}

\section{Kesimpulan}

Berdasarkan hasil analisis dalam yang dilakukan terhadap model balok dengan variasi jarak antar sengkang didaerah tekan dapat disimpulkan sebagai berikut:

1. Dengan rapatnya jarak antar sengkang didaerah tekan membuat nilai momen ultimit dan kurvatur ultitmit dari model balok bertambah naik. Nilai momen ultimit pada model dengan jarak antar sengkang 40, 80 dan $120 \mathrm{~mm}$, nilainya turun berturut-turut pada rasio 1.0000 ; $0.9621 ; 0.9242$ menjadi sebesar 5.5688; 5.3578; $5.1469 \mathrm{kNm}$. Nilai momen ultimit pada model dengan jarak antar sengkang 150; 125; 100; 75; dan 50, nilainya naik berturut-turut pada rasio $1.0000 ; \quad 1.0256 ; \quad 1.0351 ; 1.0586 ; 1.0628$ menjadi sebesar 7,9288; 8.1253; 8.2013; $8.3869 ; 8.4209 \mathrm{kNm}$

2. Dengan rapatnya jarak antar sengkang didaerah tekan membuat nilai daktilitas kurvatur dari model balok semakin besar. Nilai daktilitas kurvatur pada model dengan jarak antar sengkang 40, 80 dan $120 \mathrm{~mm}$, nilainya turun berturut-turut pada rasio $1.0000 ; 0.8667$; 0.6842 menjadi sebesar $15.3864 ; 13.3333$; 10.5263. Nilai daktilitas kurvatur pada model dengan jarak antar sengkang $150 ; 125 ; 100 ; 75$; dan $50 \mathrm{~mm}$, nilainya naik berturut-turut pada rasio $1.0000 ; 1.1081 ; 1.1714 ; 1.2424 ; 1.3667$ menjadi sebesar $4.8780 ; 5.4054 ; 5.7143$; 6.0606; 6.6667.

3. Besarnya kenaikan daktilitas kurvatur terhadap jarak antar sengkang ditengah bentang balok, nilainya dapat dihitung dari persamaan regresi polynomial curve fitting berderajat 2, yaitu:

$\mu_{\varphi}=-2.10^{-5} S^{3}+0.005 . S^{2}-0.688 . S+30.58 ;$ dengan nilai $\mu_{\varphi}$ dan $\mathrm{S}$ masing-masing:

$\boldsymbol{\mu}_{\varphi}=$ Daktilitas kurvatur;

$\boldsymbol{S}=$ Jarak antar sengkang ditengah bentang, satuan dalam mm.

$\boldsymbol{P}=$ Beban yang terjadi pada balok, satuan dalam $\mathrm{kN}$;

$\boldsymbol{\Delta}=$ Deformasi yang terjadi pada balok, satuan dalam mm.

4. Dengan rapatnya jarak antar sengkang didaerah tekan, tidak mempengaruhi beban dan deformasi pada retak pertama model balok.

\section{Saran}

Dalam penelitian ini terdapat beberapa kelemahan yang perlu dilakukan kajian lebih dalam lagi, diantaranya:

1. Dengan rapatnya jarak sengkang ditengah bentang balok, maka nilai momen-kurvatur ultimit dan daktilitas kurvatur menjadi naik.

2. Dengan meningkatnya mutu beton, mutu baja tulangan dan diameter baja tulangan, nilai daktilitas kurvatur yang terjadi menjadi lebih kecil. Perlu dilakukan penelitian lebih lanjut mengenai mutu beton, mutu baja tulangan dan diameter baja tulangan yang sesuai terhadap nilai daktilitas kurvatur yang direncanakan.

\section{DAFTAR PUSTAKA}

ANSYS Release 9.0. (2007). Programmer's Manual for ANSYS. ANSYS Incorporations and ANSYS Europe, Ltd. (http://ansys.com diakses tanggal 5 September 2009)

Basuki. Hidayati, N. (2006). Tinjauan Kuat Geser Sengkang Alternatif Dan Sengkang Konvensional Pada Balok Beton Bertulang. Dinamika Teknik Sipil. Volume 6. Nomor 1. pp. 36-45 
Institut Teknologi Sepuluh November Surabaya. (2007). Tata Cara Perhitungan Struktur Beton Untuk Bangunan Gedung (SNI 032847-2002). Edisi pertama. ITS Press. Surabaya. Indonesia

Dipohusodo, I. (1994). Struktur Beton Bertulang. Gramedia Pustaka Utama, Jakarta.

Kenneth, M.L. (1997). Reinforced Concrete Design. Mc. Graw Hill. Singapore

Park, R. Paulay, T. (1975). Reinforced Concrete Structures. John Wiley \& Sons. New York. USA

Purwono, R. (2005). Tata Cara Perhitungan Struktur Beton Bertulang Tahan Gempa (SNI 03-1726-2002). Edisi ketiga ITS Press. Surabaya. Indonesia

Taufik, S. (2009). Curve Fitting. Modul Kuliah Metode Numerik Terapan. Jurusan Teknik Struktur Program Pascasarjana Magister Teknik Sipil Universitas Lambung Mangkurat.

Tjitradi, D. Taufik, S. Kosasih, B.L. (2003). Perhitungan Kapasitas Penampang Kolom Beton Mutu Tinggi Yang Terkekang Dengan Blok Tegangan Segiempat Ekivalen. Civil Engineering Dimension. Vol.5 No.1. pp. 4550

Wahyudi, L. (1997). Struktur Beton Bertulang. Gramedia Pustaka Utama, Jakarta.

Bambang Suhendro, Teori Model Structur dan Teknik Eksperimental

Standar Nasional Indonesia (SNI),SNI 03-28472002 \& S-2002, Tata Cara Perhitungan Structur Beton, Untuk Bangunan Gedung. 